\title{
Low-Temperature Heat Treatment of PinK SAPPHIRES From ILAKAKA, MADAGASCAR
}

Sudarat Saeseaw, Charuwan Khowpong, and Wim Vertriest

Low-temperature heat treatment is often applied to gem corundum to improve its appearance. Pink sapphires from Madagascar, one of the most important sapphire-producing countries, are no exception. Therefore, characterizing Madagascan pink sapphire before and after heat treatment helps laboratories develop criteria for treatment detection. This study showed that after heat treatment at $800^{\circ} \mathrm{C}$, a subtle blue tint was removed, making the color a purer pink. Only slight alterations of monazite inclusions and iron stains in fissures were observed following these heating conditions. Other common inclusions such as needles, particles, etch tubes, and mica and zircon crystals remained unaffected. Interestingly, the monazite crystal inclusions changed color from orange-brown to near-colorless after heat treatment. Raman spectroscopy was used to detect the effect of heat treatment on zircon and monazite crystals. While the Raman spectra of zircon remained unchanged, except in the region of $1000 \mathrm{~cm}^{-1}$ after heating at $1000^{\circ} \mathrm{C}$, the Raman peaks of monazite crystals became sharper with increasing temperature. We measured full width half maximum at $\sim 976 \mathrm{~cm}^{-1}\left(\mathrm{v}_{1}\right.$, related to the $\mathrm{PO}_{4}$ group of monazite) after all annealing steps. The results showed that the width decreased around $5 \mathrm{~cm}^{-1}$ after heating at $1000^{\circ} \mathrm{C}$. This study also showed that Fourier-transform infrared (FTIR) spectroscopy, specifically the peak at $3232 \mathrm{~cm}^{-1}$, is a useful technique to detect low-temperature heat treatment in pink sapphires from Madagascar.

$\mathrm{H}$ eat treatment has been used to improve the color and/or clarity of corundum for more than a thousand years. Various parameters such as temperature, heating and cooling time, and oxidizing or reducing atmosphere will affect the final color (Emmett and Douthit, 1993; Emmett et al., 2003; Hughes et al., 2017). The border between high- and low-temperature heat treatment has been defined by Emmett (in Hughes et al., 2017) as the temperature needed to dissolve second-phase microcrystals, which is somewhere between $1200^{\circ}$ and $1350^{\circ} \mathrm{C}$. Heating at high temperatures will damage most inclusions in ruby and sapphire and is often detectable by trained gemologists. In contrast, heating corundum at low temperatures, sometimes below $700^{\circ} \mathrm{C}$, will only subtly affect their internal inclusions, making the treatment much more challenging to detect without advanced instrumentation (figure 1).

See end of article for About the Authors and Acknowledgments.

Gems \& Gemology, Vol. 56, No. 4, pp. 448-457,

http://dx.doi.org/10.5741/GEMS.56.4.448

(C) 2020 Gemological Institute of America
Previous studies on the effect of low-temperature heat treatment on inclusions have focused on rubies from Mozambique (Pardieu et al., 2015; Sripoonjan et

\section{In Brief}

- The subtle blue tint in many pink sapphires from Madagascar can be lightened or removed by heating at $800^{\circ} \mathrm{C}$ for 120 minutes in air.

- FTIR spectroscopy is a crucial technique to detect low-temperature heat treatment. The presence of the $3232 \mathrm{~cm}^{-1}$ peak is an indicator of heat treatment in Madagascan pink sapphire.

- Careful observation of monazite crystal inclusions showed a change in color from orange-brown to nearcolorless after low-temperature heat treatment.

- Raman spectroscopy can be used to detect the annealing of monazite during low-temperature treatment.

al., 2016; Saeseaw et al., 2018) and blue sapphires from Madagascar (Krzemnicki, 2010; Hughes and Perkins, 2019|. In these studies, rubies showed slight inclusion alterations when heated to $900^{\circ} \mathrm{C}$ and developed clear 


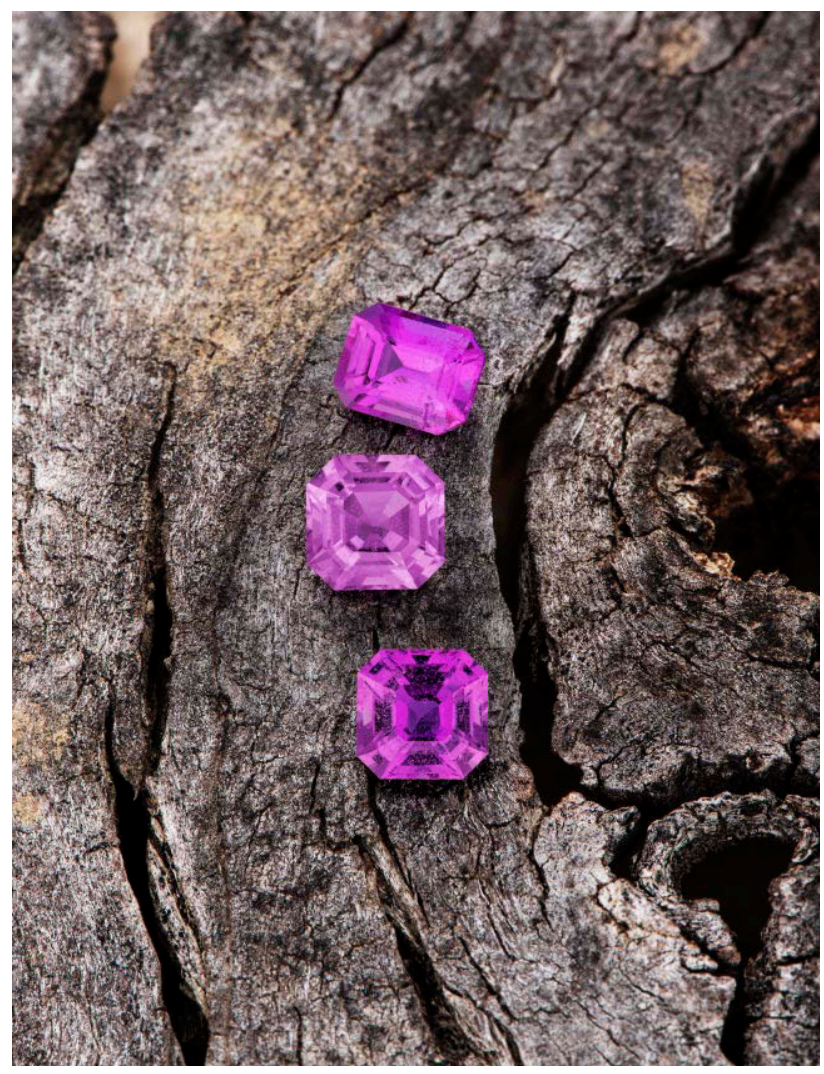

Figure 1. These pink sapphires from Ilakaka,

Madagascar, underwent low-temperature heat treatment. From top to bottom, they weigh $1.16 \mathrm{ct}, 1.17 \mathrm{ct}$, and $1.06 \mathrm{ct}$. Photo by Robert Weldon/GIA; courtesy of Jeff Hapeman, Earth's Treasury.

FTIR signatures after heat treatment. This article focuses on the effects of low-temperature heat treatment on inclusions, such as zircon and monazite, and the FTIR spectra of pink sapphire from Madagascar. This is the first study to report the use of Raman spectroscopy to analyze monazite inclusions in corundum during heat treatment experiments.

\section{MATERIALS AND METHODS}

Samples and Instruments. Fourteen samples reportedly from Ilakaka, Madagascar, were selected and polished with at least two windows for data analysis. Sample sizes ranged from 0.41 to $2.15 \mathrm{ct}$. The first set of samples (PS01-PS11) consisted of 11 pink sapphires (table 1). Samples PS01-PS08 and PS11 were purchased directly from the miner, but not at the mine site near the Taheza River in Ilakaka. These samples are classified as C-type samples in GIA's colored stone reference collection (Vertriest et al., 2019). Sample PS09 was acquired from a trader in the Ilakaka market and was reportedly from the Ambala-
TABLE 1. Color-calibrated photos of samples PS01-PS11 before (left) and after (right) heat treatment at $800^{\circ} \mathrm{C}$ for 160 minutes.

Sample ID


TABLE 2. Color-calibrated photos of samples PS21-PS23 for the secondary experiment (samples were kept at the maximum temperature for 120 minutes).

\begin{tabular}{|c|c|c|c|c|c|c|}
\hline $\begin{array}{l}\text { Sample } \\
\text { ID }\end{array}$ & Before heating & $\begin{array}{l}\text { After heating at } \\
200^{\circ} \mathrm{C}\end{array}$ & $\begin{array}{l}\text { After heating at } \\
400^{\circ} \mathrm{C}\end{array}$ & $\begin{array}{l}\text { After heating at } \\
600^{\circ} \mathrm{C}\end{array}$ & $\begin{array}{l}\text { After heating at } \\
800^{\circ} \mathrm{C}\end{array}$ & $\begin{array}{l}\text { After heating at } \\
1000^{\circ} \mathrm{C}\end{array}$ \\
\hline PS21a & & & & & & \\
\hline PS22 & & & & & & \\
\hline PS23 & & & & & & \\
\hline
\end{tabular}

vihy mining area. This sample is classified as an Etype sample. PS10 was purchased from miners at the Sakameloka washing site, which makes it a B-type sample.

A second set of three pink sapphires, containing zircon and monazite inclusions (PS21-PS23), was used for a follow-up heating experiment (table 2). Sample PS21 was purchased from the miners at the Ambarazy mine; therefore, it is C-type. GIA field gemologists witnessed the mining of samples PS22 and PS23 in the Esoki and Besatra areas, respectively. These samples are classified as B-type (Vertriest et al., 2019).

To compare the true color of the samples before and after treatment, we used a Canon EOS 5D camera with a Canon Macro MP-E $65 \mathrm{~mm}$ lens to produce consistent results. Photographs were taken under identical lighting conditions, with the reference samples placed in a Logan Electric Tru-View 810 color-corrected lightbox (5000 K lamp). A neutral-density filter was used to calibrate the camera/lightbox combination to produce a neutral gray background.

Photomicrographs of internal inclusions were captured at different magnifications with a Nikon SMZ18 system and under different types of illumination, together with a fiber-optic light source.

Non-polarized FTIR spectra were collected using a Thermo Fisher Nicolet 6700 FTIR spectrometer equipped with an XT-KBr beam splitter and a mercury-cadmium-telluride (MCT) detector operating with a $4 \times$ beam condenser accessory. The resolution was set at $4 \mathrm{~cm}^{-1}$ with $1.928 \mathrm{~cm}^{-1}$ data spacing. Infrared spectra were collected in the same area of each sample before and after heat treatment.

Raman spectra were obtained using a Renishaw inVia Raman microscope fitted with a Stellar-REN Modu Ar-ion laser producing highly polarized light at $514 \mathrm{~nm}$. For internal inclusion analysis, the system was operated in confocal mode with $20 \times$ and $50 \times$ objectives. Calibration using neon emission lines and the silicon signal at $520 \mathrm{~cm}^{-1}$ provided wavenumber accuracy within $\pm 0.5 \mathrm{~cm}^{-1}$. Spectra were collected in the $1500-200 \mathrm{~cm}^{-1}$ region.

Heating Experiment. The pink sapphires were separated into two experimental groups. First, 11 samples (PS01-PS11) were subjected to heat treatment in air at $800^{\circ} \mathrm{C}$ for 160 minutes to study the effect on color, inclusions, and infrared spectroscopy. The second set consisted of three samples (PS21-PS23) that were heated at $200^{\circ}, 400^{\circ}, 600^{\circ}, 800^{\circ}$, and $1000^{\circ} \mathrm{C}$ for 120 minutes at each step to study the changes in monazite and zircon inclusions using Raman spectroscopy.

Samples were placed on an alumina ceramic felt $\left(99.8 \% \mathrm{Al}_{2} \mathrm{O}_{3}\right)$ in a Thermo Scientific FB1400 Thermolyne benchtop $1100^{\circ} \mathrm{C}$ muffle furnace and heated to the desired temperature at a rate of $5^{\circ} \mathrm{C} / \mathrm{min}$. At the end of each heating cycle, the furnace was switched off. When the temperature of the furnace dropped 
FTIR SPECTRA

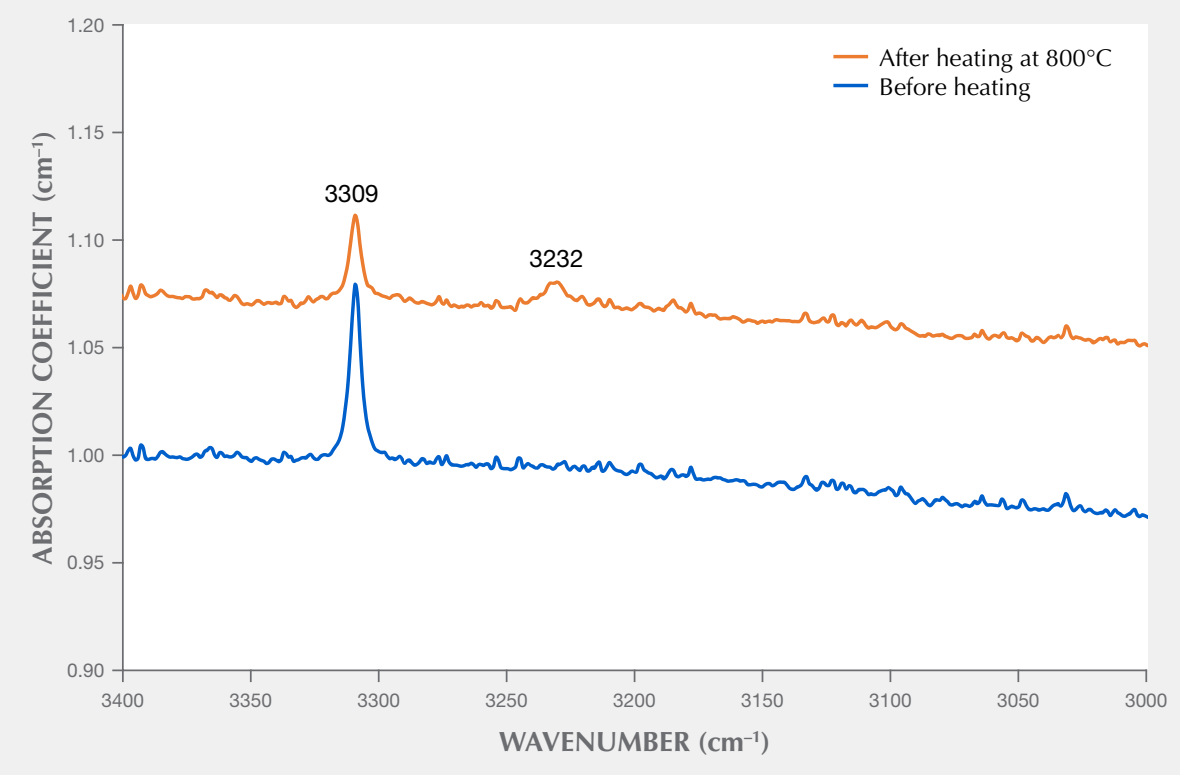

Figure 2. Comparison of non-polarized FTIR spectra before (blue) and after (orange) heat treatment at $800^{\circ} \mathrm{C}$ for 160 minutes on an unoriented pink sapphire from Madagascar. Spectra are offset vertically for clarity. below $600^{\circ} \mathrm{C}$, the samples were removed and allowed to cool to room temperature. Samples were analyzed at room temperature after each heating cycle.

\section{RESULTS AND DISCUSSIONS}

Color Appearance and Gemological Properties. Before heating, most of the samples in the first set were purplish pink. After the heat treatment process, they changed to a purer pink (table 1). These sapphires showed a significant reduction in the blue color component when heated at $800^{\circ} \mathrm{C}$ for 160 minutes, which had also been observed in rubies from Mozambique. Gemological properties were consistent for corundum and did not change during the heating experiment. Fluorescence was strong to medium red under longwave and medium to weak under short-wave UV light, both pre- and post-treatment. Chalky white fluorescence is sometimes observed in heated sapphire, caused by a charge transfer between $\mathrm{O}^{2-}$ and $\mathrm{Ti}^{4+}$ ions (Emmett et al., 2017); however, none of the samples studied showed chalky fluorescence after treatment.

Infrared Spectroscopy. Previous studies on Mozambican rubies (Pardieu et al., 2015; Saeseaw et al., 2018) have shown that only samples with a single peak at $3309 \mathrm{~cm}^{-1}$ will develop a 3309 series (3309, 3232 , and/or $3185 \mathrm{~cm}^{-1}$ ), which can be used as an indication of heat treatment. This criterion is effective for some blue sapphires (Hughes and Perkins, 2019) but is not valid for basalt-related blue sapphires.
In this study, we selected Ilakaka samples that had an obvious peak at $3309 \mathrm{~cm}^{-1}$. All samples in the first set showed a decreased $3309 \mathrm{~cm}^{-1}$ peak after heating, while 9 out of 11 samples developed a peak at $3232 \mathrm{~cm}^{-1}$, as shown in figure 2 and table 3 . No $3185 \mathrm{~cm}^{-1}$ peak was observed in this experiment. This observation has been previously reported (Saeseaw and Khowpong, 2019). The strength of the $\mathrm{OH}$ absorption bands at 3309,3232 , and $3185 \mathrm{~cm}^{-1}$ is re-

TABLE 3. Comparison of FTIR peak heights before and after heat treatment at $800^{\circ} \mathrm{C}$ for 160 minutes.

\begin{tabular}{lccc}
\hline \multirow{2}{*}{ Sample ID } & Before heating & \multicolumn{2}{c}{ After heating } \\
\cline { 2 - 4 } & $3309 \mathrm{~cm}^{-1}$ & $3309 \mathrm{~cm}^{-1}$ & $3232 \mathrm{~cm}^{-1}$ \\
\hline PS01 & 0.04 & $\mathrm{nd}$ & $\mathrm{nd}$ \\
PS02 & 0.04 & 0.02 & 0.005 \\
PS03 & 0.07 & 0.04 & 0.01 \\
PS04 & 0.07 & 0.04 & 0.01 \\
PS05 & 0.04 & 0.02 & $\mathrm{nd}$ \\
PS06 & 0.05 & 0.02 & 0.01 \\
PS07 & 0.05 & 0.03 & 0.01 \\
PS08 & 0.06 & 0.03 & 0.01 \\
PS09 & 0.06 & 0.03 & 0.01 \\
PS10 & 0.06 & 0.03 & 0.01 \\
PS11 & 0.04 & 0.01 & 0.005 \\
\hline
\end{tabular}

Abbreviation: $n d=$ not detected 
lated to the orientation of the crystal and the polarization of the light used to analyze the sample. They are strongest when collected perpendicular to the caxis and are related to the presence of certain trace elements. The peak height absorption coefficient of the $3185 \mathrm{~cm}^{-1}$ peak is only one-third that of the peak at $3232 \mathrm{~cm}^{-1}$; therefore, it rarely presents on small stones (Beran, 1991).

However, it is worth noting that only when the peak height absorption coefficient of the $3309 \mathrm{~cm}^{-1}$ peak is greater than or equal to $0.04 \mathrm{~cm}^{-1}$ before heating will it develop a $3232 \mathrm{~cm}^{-1}$ peak after treatment. Absorption coefficient or $\mathrm{cm}^{-1}$ is related to the thickness of a sample. Therefore, a small sample might not show the $3232 \mathrm{~cm}^{-1}$ peak since the path length of the light through the stone is much shorter. This means that the feature is easier to detect in larger stones, while smaller stones will have "no indication of heat treatment" based on FTIR spectra.

We also collected FTIR spectra on 250 additional unheated pink sapphires reportedly from Madagascar. The results showed 130 samples with only the single $3309 \mathrm{~cm}^{-1}$ peak, and none of these samples showed a 3309 series. Therefore, it is important to ensure that spectra are either collected perpendicular to the c-axis, taken in multiple directions, or collected using a diffuse reflectance (DRIFT) accessory to obtain high sensitivity of the $3232 \mathrm{~cm}^{-1}$ peak.

Internal Features. Visual Observations. Pink sapphires from Madagascar commonly contain numerous zircon crystals (figure 3A). Zircon crystals typically have a rice grain shape and can occur as clusters or single crystals (figure 3B), sometimes with tension halos, similar to discoid fractures that develop around crystals after heat treatment (figure 3C). Needles, particles, thin films, etch tubes, and twinning can also be observed (figure $3 \mathrm{D}$ and $3 \mathrm{E}$ ), as can

Figure 3. Typical inclusion scenes in pink sapphire from Madagascar before (left) and after (right) heat treatment at $800^{\circ} \mathrm{C}$ for 160 minutes. Numerous zircon crystals (A) and clusters of zircon crystals (B). C: Zircon with tension halos; the fracture expanded slightly after heating. D: Minute particles, needles, and platelets. E: Etch tubes with natural fractures. F: Large mica crystal and smaller isolated zircon crystals. G: Monazite crystals that altered from orange-brown to near-colorless, some developing tension fractures after heat treatment (see arrows). H: Zircon and fracture with iron stains. Photomicrographs by Charuwan Khowpong. Fields of view $2.85 \mathrm{~mm}(A), 1.05 \mathrm{~mm}$ (B$C, H), 1.75 \mathrm{~mm}(D, F-G)$, and $3.65 \mathrm{~mm}(E)$.
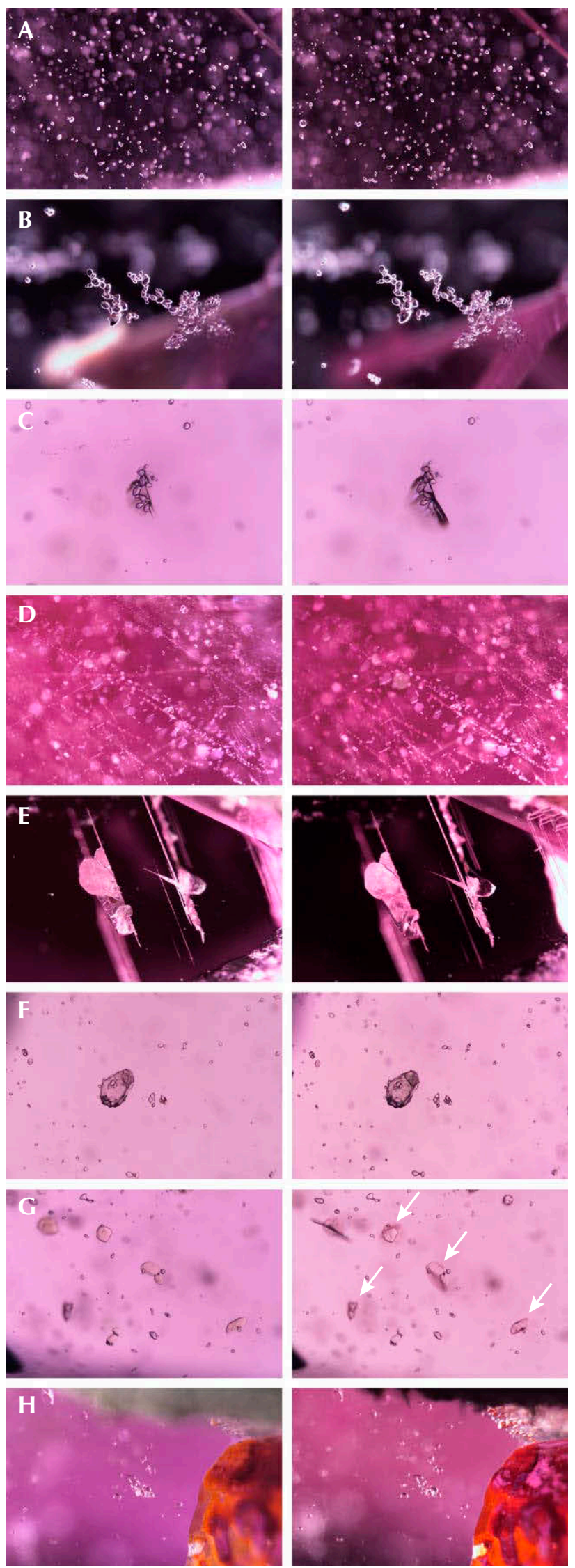

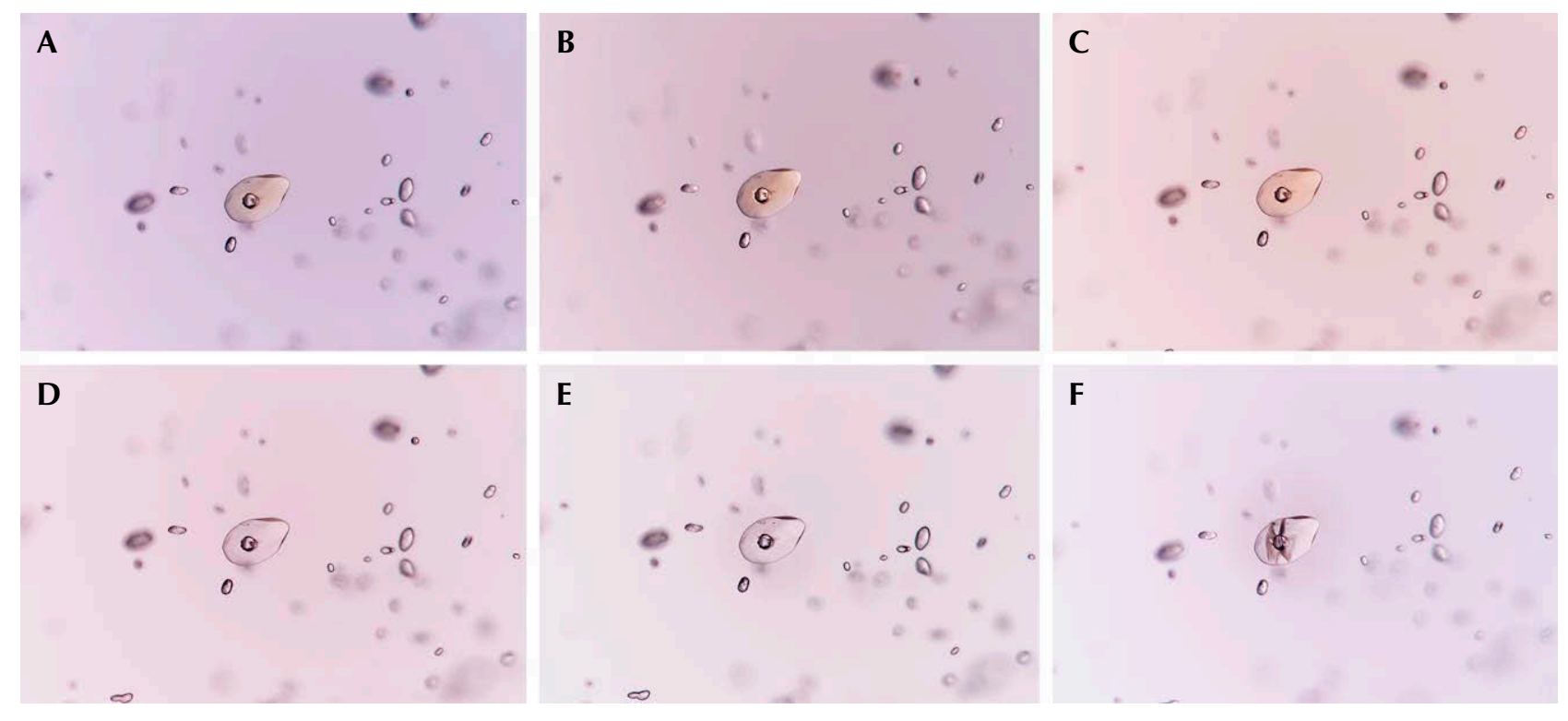

Figure 4. Reaction of a monazite crystal prior to heating and after being heated to $200^{\circ}, 400^{\circ}, 600^{\circ}, 800^{\circ}$, and $1000^{\circ} \mathrm{C}(\mathrm{A}-\mathrm{F})$. The orange-brown color of the crystal disappeared after heating to $600^{\circ} \mathrm{C}(\mathrm{D})$, and it developed a tension crack at $1000^{\circ} \mathrm{C}$ (F). The small crystal visible inside the monazite was identified by Raman spectroscopy as zircon. Photomicrographs by Charuwan Khowpong; field of view $1.05 \mathrm{~mm}$.

crystals of mica (figure 3F) and monazite (figure 3G). The monazite crystals typically have an orangy color; this is due to natural radiation damage caused by a relative enrichment in radioactive elements such as uranium and thorium (Ruschel et al., 2012). A few stones featured inclusions within inclusions, with zircon crystals embedded in monazite or mica crystals (figure 3F).

During the first experiment with samples PS01-PS11, most of the inclusions, including zircon, showed no change when heated at $800^{\circ} \mathrm{C}$ for $160 \mathrm{mi}$ nutes. After treatment, orange epigenetic iron stains in surface-reaching fissures became darker due to the oxidation and dehydration of iron minerals at higher temperatures (figure $3 \mathrm{H}$ ). Typically the orange iron stains consist of limonite $(\alpha-\mathrm{FeO}(\mathrm{OH}))$ and convert to brownish red hematite $\left(\alpha-\mathrm{Fe}_{2} \mathrm{O}_{3}\right)$ during heat treatment (Koivula, 2013; Sripoonjan et al., 2016). The other observed change was seen in monazite crystals, which changed color from orange-brown to near-colorless after heat treatment. In some cases, tension fractures also formed (figure 3G).

Focus on Monazite and Zircon. The most likely explanation for the change of color in the monazite inclusion is the annealing of the radiation damage caused by radioactive elements that substituted in the crystal lattice. Monazite is a phosphate mineral rich in rare earth elements such as cerium, lantha- num, and neodymium (Clavier et al., 2011). It is radioactive due to the presence of thorium and, to a lesser degree, uranium. Other minerals such as zircon and baddeleyite can also contain radioactive elements. These elements are of great interest in geological studies since they can be used to date minerals based on the radioactive decay of those trace elements. Age dating research is mostly focused on zircon, where small amounts of uranium are common in the lattice (Dickin, 2018).

A side effect of radioactivity is the slow damage to the crystal structure, which is seen as the orangebrown color in the monazite inclusions. The term metamict indicates that a gem (most often zircon) has strongly altered properties (RI, SG, toughness, etc.) because of its internal radiation damage. Such radiation damage can distort the crystalline structure to such a degree that it becomes non-crystalline (amorphous). An example is "low" zircon from Sri Lanka.

The initial heat treatment experiment strongly suggests that heat treatment can undo this radiation damage, healing the crystal lattice to its original undamaged state (Meldrum et al., 1998; Nasdala et al., 2002).

To further study the potential healing of radiation damage in inclusions, we continued our heating experiment on selected samples (table 2) containing monazite and zircon inclusions. Both of these minerals commonly include radioactive elements and 


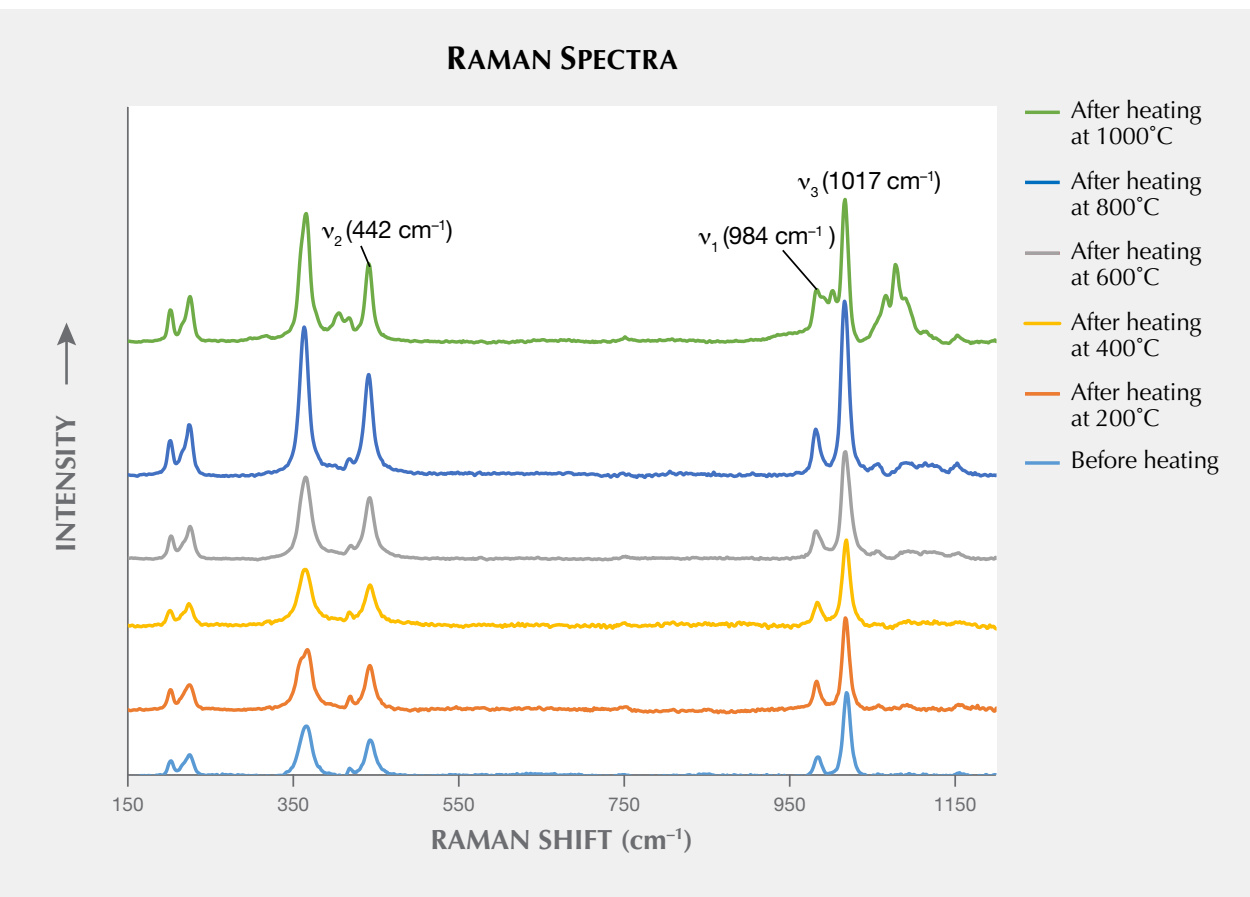

Figure 5. Stacked

Raman spectra of a zircon inclusion in sample PS23 before and after heat treatment at each step. Peaks in the 1000$1100 \mathrm{~cm}^{-1}$ region are due to luminescence observed in the sample after heating to $1000^{\circ} \mathrm{C}$. FWHM measured by GRAMS software.

potentially have crystal structure damage induced by radioactivity. They may also be annealed at higher temperatures.

In this heating experiment, the temperature was increased from $200^{\circ} \mathrm{C}$ to $1000^{\circ} \mathrm{C}$ at $200^{\circ} \mathrm{C}$ intervals with a two-hour heating duration. Data was collected between every step. Results showed that the color of a monazite crystal did not change when heated at $200^{\circ} \mathrm{C}$ and $400^{\circ} \mathrm{C}$, but started to fade after heating above $600^{\circ} \mathrm{C}$ (figure 4D). A tension fracture developed after heating at $1000^{\circ} \mathrm{C}$ (figure $4 \mathrm{~F}$ ).

Raman spectroscopy was introduced in 1995 as a method to estimate the degree of radiation damage in minerals, such as in zircon and monazite (Nasdala et al., 1995). In this study, we used Raman to analyze zircon and monazite inclusions in Madagascan pink sapphires. The results will be discussed separately.

Zircon. We analyzed 31 randomly chosen zircon inclusions with and without tension halos from the three sapphires in the second set. Raman spectra (figure 5) showed characteristic zircon peaks at 201.3, 223.8, 364.5, 442.2 $\left(v_{2}\right), 984.0\left(v_{1}\right)$, and $1016.8\left(v_{3}\right) \mathrm{cm}^{-1}$. It is well known that the three main peaks at 442.2 , 984.0, and $1016.8 \mathrm{~cm}^{-1}$ are related to internal $\mathrm{SiO}_{4}$ vibration modes, and the three other peaks at 201.3, 223.8 , and $364.5 \mathrm{~cm}^{-1}$ are lattice vibrational modes involving interactions between $\mathrm{SiO}_{4}$ tetrahedra and the $\mathrm{Zr}$ atom. The peak at $1016.8 \mathrm{~cm}^{-1}$ or $v_{3}\left(\mathrm{SiO}_{4}\right)$ is

TABLE 4. Results of Raman analyses of zircon inclusions or $v_{3}\left(\mathrm{SiO}_{4}\right)$ in pink sapphire, reported in average \pm SD $(n=$ number of analyzed crystals).

\begin{tabular}{|c|c|c|c|c|c|c|}
\hline \multirow{2}{*}{$\begin{array}{l}\text { Annealing } \\
\text { temperature } \\
\left({ }^{\circ} \mathrm{C}\right)\end{array}$} & \multicolumn{2}{|c|}{ Sample PS21 $(n=15)$} & \multicolumn{2}{|c|}{ Sample PS22 $(\mathrm{n}=8)$} & \multicolumn{2}{|c|}{ Sample PS23 $(\mathrm{n}=8)$} \\
\hline & $\begin{array}{l}\text { Peak position } \\
\quad\left(\mathrm{cm}^{-1}\right)\end{array}$ & $\begin{array}{c}\text { Measured } \\
\text { FWHM }\left(\mathrm{cm}^{-1}\right)\end{array}$ & $\begin{array}{l}\text { Peak position } \\
\quad\left(\mathrm{cm}^{-1}\right)\end{array}$ & $\begin{array}{c}\text { Measured } \\
\text { FWHM }\left(\mathrm{cm}^{-1}\right)\end{array}$ & $\begin{array}{c}\text { Peak position } \\
\left(\mathrm{cm}^{-1}\right)\end{array}$ & $\begin{array}{c}\text { Measured } \\
\text { FWHM }\left(\mathrm{cm}^{-1}\right)\end{array}$ \\
\hline- & $1009.9 \pm 1.7$ & $11.3 \pm 2.5$ & $1011.8 \pm 3.1$ & $10.4 \pm 1.5$ & $1016.8 \pm 3.0$ & $10.4 \pm 1.5$ \\
\hline 200 & $1009.7 \pm 1.9$ & $11.2 \pm 2.7$ & $1012.0 \pm 2.2$ & $9.9 \pm 1.7$ & $1016.0 \pm 3.1$ & $9.9 \pm 1.7$ \\
\hline 400 & $1009.5 \pm 1.9$ & $10.8 \pm 2.8$ & $1010.8 \pm 2.8$ & $9.4 \pm 1.3$ & $1015.5 \pm 4.1$ & $9.4 \pm 1.3$ \\
\hline 600 & $1009.6 \pm 1.5$ & $9.9 \pm 1.8$ & $1011.7 \pm 2.1$ & $9.4 \pm 2.0$ & $1015.6 \pm 3.1$ & $9.4 \pm 2.0$ \\
\hline 800 & $1010.1 \pm 1.2$ & $8.6 \pm 1.0$ & $1009.0 \pm 1.5$ & $9.8 \pm 1.6$ & $1015.4 \pm 3.3$ & $9.8 \pm 1.6$ \\
\hline 1000 & $1010.2 \pm 1.3$ & $10.4 \pm 2.3$ & $1008.8 \pm 1.0$ & $8.6 \pm 2.0$ & $1014.6 \pm 1.1$ & $8.2 \pm 1.3$ \\
\hline
\end{tabular}




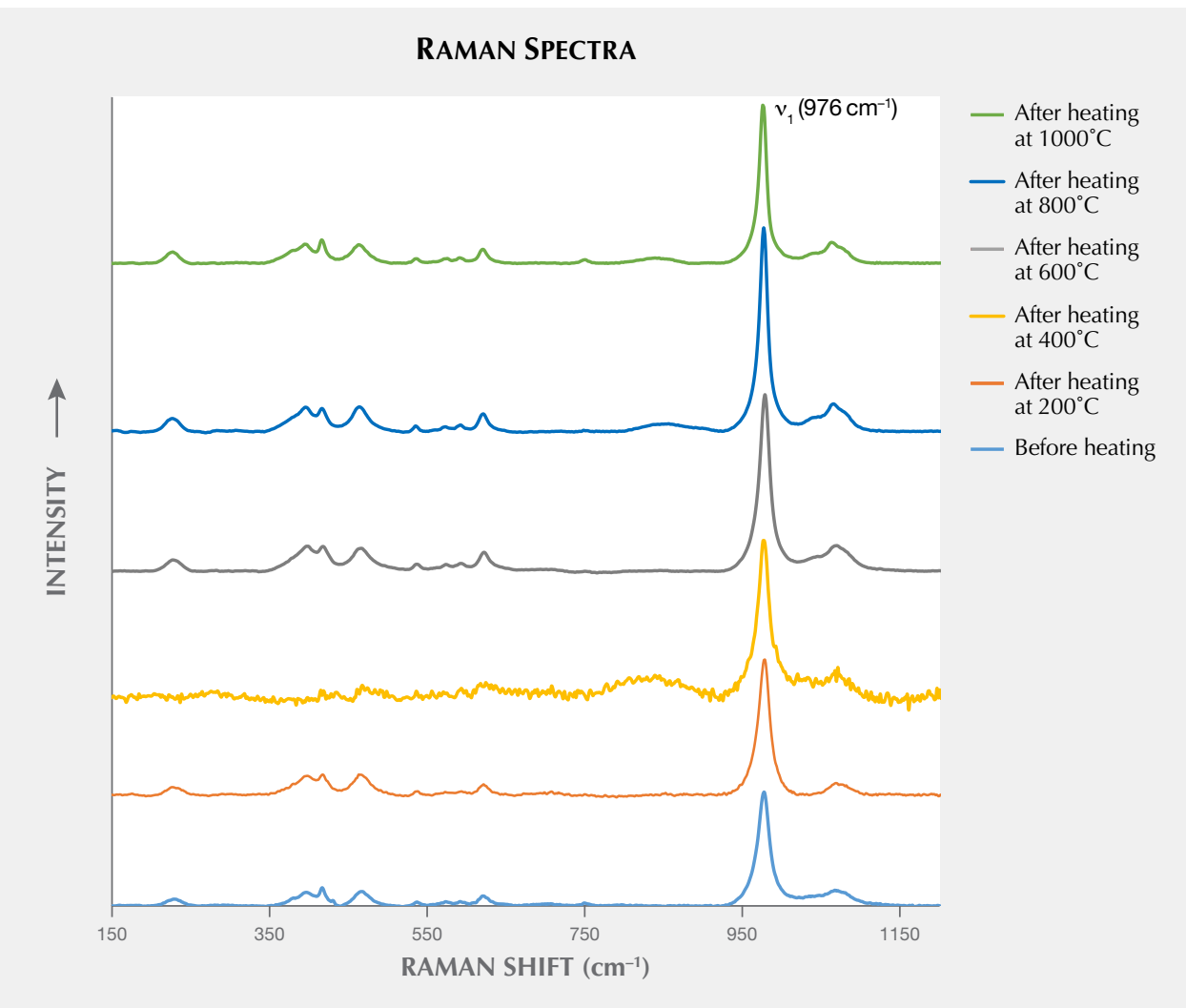

Figure 6. Stacked Raman spectra of one monazite crystal in sample PS23 before and after heat treatment. FWHM was measured by GRAMS software. the most sensitive to the accumulation of radiation damage, and therefore it is commonly used to compare the structural state of radiation.

Before heating, $v_{3}$ peak positions were at about 1009.9 and $1011.8 \mathrm{~cm}^{-1}$ on average for samples PS21 and PS22, respectively. The peak of zircon crystals in sample PS23 was at a slightly higher wavenumber, around $1016.8 \mathrm{~cm}^{-1}$; see table 4 . The differences in peak position are affected by many factors, such as chemical composition, pressure, and temperature. However, those differences are beyond the scope of this study.

After heating, we found insignificant changes to Raman peaks where FWHM of the $v_{3}$ peak ranged from 8.6 to $11.3 \mathrm{~cm}^{-1}$. These numbers were reported as a partially metamict state (Nasdala et al., 1995; Palenik et al., 2003). At $1000^{\circ} \mathrm{C}$, we found 10 out of 31 zircons developed peaks in the range of 950 and $1150 \mathrm{~cm}^{-1}$ (which might be luminescence features (Krzemnicki, 2010). However, these features were not observed when the Raman spectra were collected using a laser with $488 \mathrm{~nm}$ wavelength instead of $514 \mathrm{~nm}$.

Significant changes in the Raman spectra of these inclusions have been reported when heated at higher temperatures (Rankin and Edwards, 2003; Wang et al., 2006). When heated above $1400^{\circ} \mathrm{C}$, the Raman spectra of these inclusions start to show baddeleyite peaks, indicating that zircon becomes unstable in these conditions and breaks down into oxides.

Monazite. Fifteen monazite inclusions from the three sapphires in the second set were studied. The Raman spectrum of monazite is presented in figure 6 and shows distinct vibrational bands in the ranges $970-1075 \mathrm{~cm}^{-1}$ and below $620 \mathrm{~cm}^{-1}$. The former is assigned to the internal $\mathrm{PO}_{4}$ stretching vibrations, whereas the latter is due to the $\mathrm{PO}_{4}$ bending and external vibrations of the $\mathrm{Ce}^{3+}$ ions and the $\left[\mathrm{PO}_{4}\right]^{3-}$ units, respectively (Ruschel et al., 2012). The most prominent peak in the Raman spectrum of monazite is at about $976 \mathrm{~cm}^{-1}$ or $v_{1}\left(\mathrm{PO}_{4}\right)$. We measured the peak position and FWHM, as shown in table 5 .

The results showed the effect of heat treatment on the peak position to be insignificant in all samples. Samples PS21 and PS22 showed a lower wavenumber of peak position and narrower peaks than those of the monazite crystals in sample PS23.

All samples showed sharper $\sim 976 \mathrm{~cm}^{-1}$ peaks during progressive heating at higher temperatures. Sample PS21 displayed decreasing width, from $14.2 \pm 0.5$ $\mathrm{cm}^{-1}$ unheated to $8.8 \pm 0.2 \mathrm{~cm}^{-1}$ after heating at 
TABLE 5. Results of Raman analyses of monazite inclusions or $v_{1}\left(\mathrm{PO}_{4}\right)$ in pink sapphire, reported in average \pm SD $(n=$ number of analyzed crystals).

\begin{tabular}{|c|c|c|c|c|c|c|}
\hline \multirow{2}{*}{$\begin{array}{l}\text { Annealing } \\
\text { temperature } \\
\left({ }^{\circ} \mathrm{C}\right)\end{array}$} & \multicolumn{2}{|c|}{ Sample PS21 $(n=6)$} & \multicolumn{2}{|c|}{ Sample PS22 $(n=6)$} & \multicolumn{2}{|c|}{ Sample PS23 $(n=2)$} \\
\hline & $\begin{array}{l}\text { Peak position } \\
\left(\mathrm{cm}^{-1}\right)\end{array}$ & $\begin{array}{c}\text { Measured } \\
\text { FWHM }\left(\mathrm{cm}^{-1}\right)\end{array}$ & $\begin{array}{c}\text { Peak position } \\
\left(\mathrm{cm}^{-1}\right)\end{array}$ & $\begin{array}{c}\text { Measured } \\
\text { FWHM }\left(\mathrm{cm}^{-1}\right)\end{array}$ & $\begin{array}{c}\text { Peak position } \\
\left(\mathrm{cm}^{-1}\right)\end{array}$ & $\begin{array}{c}\text { Measured } \\
\text { FWHM }\left(\mathrm{cm}^{-1}\right)\end{array}$ \\
\hline- & $974.0 \pm 0.8$ & $14.2 \pm 0.5$ & $974.0 \pm 1.3$ & $15.9 \pm 0.3$ & $976.5 \pm 0.3$ & $18.4 \pm 0.1$ \\
\hline 200 & $973.9 \pm 0.8$ & $14.3 \pm 0.3$ & $974.1 \pm 1.3$ & $15.8 \pm 0.4$ & $976.2 \pm 0.5$ & $18.1 \pm 0.5$ \\
\hline 400 & $974.0 \pm 0.5$ & $12.5 \pm 1.1$ & $974.0 \pm 1.1$ & $14.9 \pm 0.2$ & $976.2 \pm 0.4$ & $17.5 \pm 0.4$ \\
\hline 600 & $974.1 \pm 0.3$ & $11.2 \pm 0.5$ & $974.6 \pm 0.8$ & $12.9 \pm 0.2$ & $976.9 \pm 0.4$ & $15.4 \pm 0.6$ \\
\hline 800 & $974.6 \pm 0.2$ & $9.6 \pm 0.2$ & $973.9 \pm 0.5$ & $11.4 \pm 0.3$ & $975.9 \pm 0.1$ & $13.3 \pm 0.4$ \\
\hline 1000 & $974.8 \pm 0.3$ & $8.8 \pm 0.2$ & $974.5 \pm 0.5$ & $9.8 \pm 0.4$ & $975.8 \pm 0.2$ & $13.3 \pm 0.4$ \\
\hline
\end{tabular}

$1000^{\circ} \mathrm{C}$. Sample PS23 also decreased in width from $18.4 \pm 0.1 \mathrm{~cm}^{-1}$ unheated to $13.3 \pm 0.4 \mathrm{~cm}^{-1}$ after heating at $800^{\circ} \mathrm{C}$. The width did not change during the heating step from $800^{\circ} \mathrm{C}$ to $1000^{\circ} \mathrm{C}$ (see figure 7). The differences between these two sets of results may be caused by chemical composition or differential degrees of initial radiation damage (which is not included in this study). Our results corresponded with previous work in which Raman spectra showed distinctly narrower bands on annealed monazite than on untreated monazite (Seydoux-Guillaume et al., 2002).

\section{CONCLUSIONS}

It has long been known that heat treatment at low temperatures helps to improve color in pink sapphires. Detecting this treatment remains challenging since inclusions such as zircon, needles, and particles are often not affected by low-temperature heat treatment. Using advanced analytical instruments such as FTIR spectrometers is necessary to help gemologists detect heat treatment. In this study on Madagascar pink sapphire, we have shown that the presence of the $3232 \mathrm{~cm}^{-1}$ peak is related to heat treatment. While this peak is only found in heated stones, its absence is not an indicator of an unheated stone. This peak will only develop if the initial $3309 \mathrm{~cm}^{-1}$ peak is strong enough. This is exactly the same behavior that has been observed in rubies from Montepuez, Mozambique.

Another possible indicator of heat treatment is the observation of monazite crystals, even though they are less common in pink sapphire than zircon crystals. Monazite typically has an orange-brown color that will fade to near-colorless after heat treatment at relatively low temperatures. This alteration can be explained by annealing radiation damage to monazite inclusions due to the increasing temperature. This also results in narrower peaks in the

Figure 7. The relative difference between FWHM of monazite at $\mathrm{v}_{1}\left(\mathrm{PO}_{4}\right)$ at $\sim 974-976 \mathrm{~cm}^{-1}$ and heating temperature on sample PS22 ( $n=6$; left) and sample PS23 ( $n=2$; right). Different dots represent different monazite inclusions analyzed in each sample (n=number of analyzed crystals).

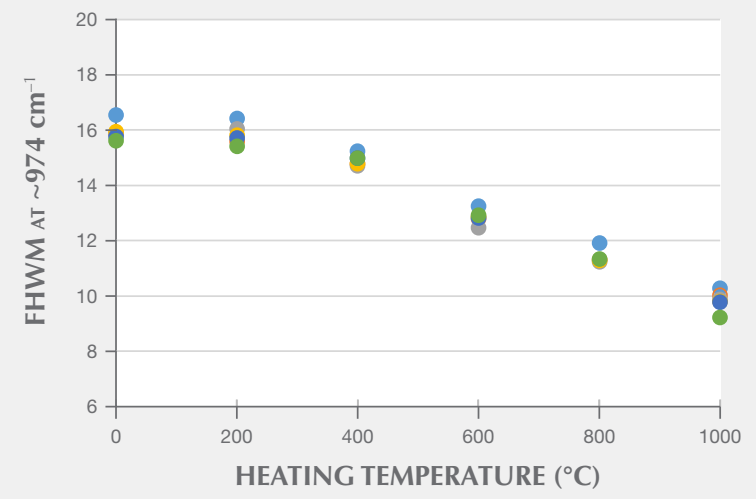

HEATING TEMPERATURE $\left({ }^{\circ} \mathrm{C}\right)$

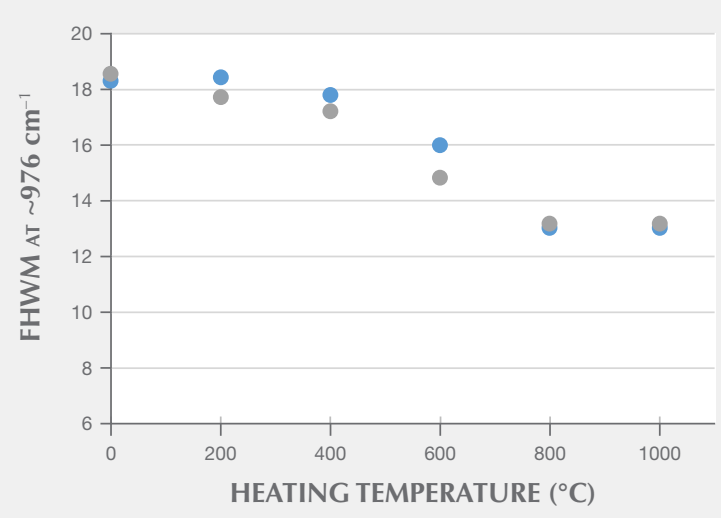

GEMS \& GEMOLOGY

WINTER 2020 
Raman spectrum. The presence of a near-colorless monazite inclusion suggests the gem has been heated, but its color is sometimes masked by the bodycolor of the host.
In order to use FWHM and other Raman spectra features as an indication of low-temperature heat treatment, more samples will be required to complete a statistically relevant analysis.

\section{ABOUT THE AUTHORS}

Ms. Saeseaw is senior manager of colored stone identification, Ms. Khowpong is an analytics technician, and Mr. Vertriest is supervisor of field gemology, at GIA in Bangkok.

\section{ACKNOWLEDGMENTS}

The authors would like to give thanks to GIA's Bangkok lab staff, especially Suwasan Wongchacree for photomicrography, Polthep Sukpanish for FTIR data, and Sasithorn Engniwat for photo calibration. Also, thanks to Aaron Palke and Shane McClure for their useful suggestions. We also thank the peer reviewers for valuable comments that improved this article.

\section{REFERENCES}

Beran A. (1991) Trace hydrogen in Verneuil-grown corundum and its colour varieties: An IR spectroscopic study. European Journal of Mineralogy, Vol. 3, No. 6, pp. 971-976, http://dx.doi.org/10.1127/ejm/3/6/0971

Clavier N., Podor R., Dacheux N. (2011) Crystal chemistry of the monazite structure. Journal of the European Ceramic Society, Vol. 31, No. 6, pp. 941-976, http://dx.doi.org/10.1016/j.jeurceramsoc.2010.12.019

Dickin A.P. (2018) Radiogenic Isotope Geology. Cambridge University Press, Cambridge, UK, https://doi.org/10.1017/9781316163009

Emmett J.L., Douthit T.R. (1993) Heat treating the sapphires of Rock Creek, Montana. GÆG, Vol. 29, No. 4, pp. 250-272, http://dx.doi.org/10.5741/GEMS.29.4.250

Emmett J.L., Scarratt K., McClure S.F., Moses T., Douthit T.R., Hughes R., Novak S., Shigley J.E., Wang W., Bordelon O., Kane R.E. (2003) Beryllium diffusion of ruby and sapphire. $G \uplus G$, Vol. 39, No. 2, pp. 84-135, http://dx.doi.org/10.5741/GEMS.39.2.84

Emmett J.L., Dubinsky E.V., Hughes R.W., Scarratt K. (2017) Color, spectra \& luminescence. In R.W. Hughes, Ed., Ruby \&) Sapphire: A Gemologist's Guide. Bangkok, pp. 107-163.

Hughes E.B., Perkins R. (2019) Madagascar sapphire: Low-temperature heat treatment experiments. $G \uplus G$, Vol. 55, No. 2, pp. 184197, http://dx.doi.org/10.5741/GEMS.55.2.184

Hughes R.W., Manorotkul W., Hughes E.B. (2017) Ruby «) Sapphire: A Gemologist's Guide. RWH Publishing/Lotus Publishing, Bangkok.

Koivula J.I. (2013) Useful visual clue indicating corundum heat treatment. $G \uplus G$, Vol. 49, No. 3, pp. 160-161, http://dx.doi.org/10.5741/GEMS.49.3.160

Krzemnicki M.S. (2010) How to get the "blues" out of the pink: Detection of low-temperature heating of pink sapphires. SSEF Facette, No. 17, p 12.

Meldrum A., Boatner L.A., Weber W.J., Ewing R.C. (1998) Radiation damage in zircon and monazite. Geochimica et Cosmochimica Acta, Vol. 62, No. 14, pp. 2509-2520, http://dx.doi.org/10.1016/S0016-7037/98/00174-4

Nasdala L., Irmer G., Wolf D. (1995) The degree of metamictization in zircon: A Raman spectroscopic study. European Journal of Mineralogy, Vol. 7, No. 3, pp. 471-478, http://dx.doi.org/10.1127/ejm/7/3/0471

Nasdala L., Lengauer C.L., Hanchar J.M., Kronz A., Wirth R., Blanc P., Kennedy A.K., Seydoux-Guillaume A.-M. (2002) Annealing radiation damage and the recovery of cathodoluminescence. Chemical Geology, Vol. 191, No. 1-3, pp. 121-140,
http://dx.doi.org/10.1016/S0009-2541(02)00152-3

Palenik C.S., Nasdala L., Ewing R.C. (2003) Radiation damage in zircon. American Mineralogist, Vol. 88, No. 5-6, pp. 770-781, http://dx.doi.org/10.2138/am-2003-5-606

Pardieu V., Saeseaw S., Detroyat S., Raynaud V., Sangsawong S., Bhusrisom T., Engniwat S., Muyal J. (2015) "Low temperature" heat treatment of Mozambique ruby. GIA Research News, https://www.gia.edu/gia-news-research-low-temperature-heattreatment-mozambique-ruby

Rankin A.H., Edwards W. (2003) Some effects of extreme heat treatment on zircon inclusions in corundum. Journal of Gemmology, Vol. 28, No. 5, pp. 257-264.

Ruschel K., Nasdala L., Kronz A., Hanchar J.M., Többens D.M. Škoda R., Finger F., Möller A. (2012) A Raman spectroscopic study on the structural disorder of monazite-(Ce). Mineralogy and Petrology, Vol. 105, No. 1-2, pp. 41-55, http://dx.doi.org/10.1007/s00710-012-0197-7

Saeseaw S., Khowpong C. (2019) Gem News International: The effect of low-temperature heat treatment on pink sapphire. $G \uplus G$, Vol. 55, No. 2, pp. 290-291.

Saeseaw S., Kongsomart B., Atikarnsakul U., Khowpong C., Vertriest W., Soonthorntantikul W. (2018) Update on "low-temperature" heat treatment of Mozambican ruby: A focus on inclusions and FTIR spectroscopy. GIA Research News, https://www.gia.edu/ongoing-research/update-low-temperature-heat-treatment-mozambican-ruby-focus-on-inclusionsand-ftir-spectroscopy

Seydoux-Guillaume A.M., Wirth R., Nasdala L., Gottschalk M., Montel J.M., Heinrich W. (2002) An XRD, TEM and Raman study of experimentally annealed natural monazite. Physics and Chemistry of Minerals, Vol. 29, No. 4, pp. 240-253, http://dx.doi.org/10.1007/s00269-001-0232-4

Sripoonjan T., Wanthanachaisaeng B., Leelawatanasuk T. (2016) Phase transformation of epigenetic iron staining: Indication of low-temperature heat treatment in Mozambique ruby. Journal of Gemmology, Vol. 35, No. 2, pp. 156-161.

Vertriest W., Palke A.C., Renfro N.D. (2019) Field gemology: Building a research collection and understanding the development of gem deposits. $G \uplus G$, Vol. 55, No. 4, pp. 490-511, http://dx.doi.org/10.5741/GEMS.55.4.490

Wang W., Scarratt K., Emmett J.L., Breeding C.M., Douthit T.R. (2006) The effects of heat treatment on zircon inclusions in Madagascar sapphires. GÆG, Vol. 42, No. 2, pp. 134-150, http://dx.doi.org/10.5741/GEMS.42.2.134 